\title{
印刷物によるバリアフリー・コミュニケーション・システムの新しい試み \\ New Approach to Barrier-Free Communication Using Paper Print
}

（株）廣済堂 樑見 拓史

Kosaido, Takushi FUKAMI

Abstract

In Japan, there has recently been an increasing interest in health, home care and welfare, as we enter into a society occupied by more and more elderly people and a smaller number of younger citizens. The Japanese government and the administrative divisions of Japan, including Tokyo, Hokkaido, Osaka, Kyoto and all the prefectures, have been adopting many kinds of health and welfare policies. As one such policy, the Ministry of Health, Labor and Welfare designated an instrument for blind people and elderly people as a "daily life tool" in April 2003. This instrument translates information printed on paper to voice reading. The Ministry's policy and the associated budget will enable blind people to purchase the instrument with very little cost. Our company developed this instrument, called "SPEECHIO," as well as the new software that converts text to two-dimensional symbol named "SP-CODE." The SPEECHIO reads SP-CODE and changes text into voice reading automatically. We believe this new barrier-free communication system will greatly help blind people and old-aged people who have difficulties in reading small prints. In this article, I describe this system and our ongoing and future activities with the system.

1.はじめに

少子・高齢化社会を迎えて健康・介護・福祉への感心が高まっている。国・都道府県・区市町 村レベルでの様々な取組みが行われているが、厚生労働省では、平成 15 年 4 月より視覚障害者 向け日常生活用具として「視覚障害者用活字文書読上げ装置」を認定し、福祉国家実現に向けた予 算を確保した。（1）この「視覚障害者用活字文書読上げ装置」とは、当社が開発した「スピーチ 才」がこの対象商品である。

また今回、紹介する新しい2 次元シンボル「SP コード」とその読上げ装置「スピーチオ」は、 視覚障害者向けバリアフリーへの新しい試みとして開発されたものです。これらの紹介と現在の 活動状況について報告する。

\section{2.「SPコード」と「スピーチオ」の概要／特徴}

2 次元シンボルは小スペースに大容量の情報を格納でき、定期券に代表される IC カードなどと 比べ、紙に印刷できるため、低コストである。当社は印刷会社であり、紙媒体での情報伝達とい う点に着目し、「誰でも簡単に利用できるコミュニケーションツール」というコンセプトのもと新 たな 2 次元シンボル「SP コード」を開発した。

すでに知られている QR CodeやData Matrix などは、1 次元バーコードを 2 次元に拡張した もので、在庫管理、物流管理、POS デー夕収集などを目的としたものである。標準化・統一化さ れた 1 次元バーコードには、UPC コードや郵便コードが代表的なものであるが、これらは英・ 数字の組合せでせいぜい $10 ２ 0$ 析である。桁数不足を補うために登場してきたのが既存の 2 次 元シンボルである。これらは市場で注目され始めているが、基本的には、英・数字を主体とした もので、100〜300 桁を対象にしている。その点、「SP コード」は英・数字のみならず日本語の 
漢字・かなを含み、テキストを対象として発案されたものである。またテキスト文字列を 2 次元 シンボルにエンコードするために、テキストデータを様々な手法、ノウハウを用いて压縮してお り、誤り訂正符号化手法によって、少々のキズやヨゴレにも耐えられる工夫や、音声合成時の辞 書にも工夫がなされている。

「SP コード」は、標準サイズ $18 \mathrm{~mm} * 18 \mathrm{~m}$ mに日本語で約 800 字を格納できる。この「SP コード」を専用読上げ装置「スピーチオ」に読み取らせると、2 次元シンボルから画像処理によ りデコードを行い、テキストデータに変換し、音声で読上げる。現在「SP コード」公式サイト より簡易版「SP コード」生成ソフト (one click edition)を無料で提供している。ぜひお試しいた だきたい。（2）このソフトをインストールすることで、Microsoft $($ word 上で簡単に「SP 一ド」作成ができるようになっている。「スピーチオ」は印刷物から情報を得ることが難しい視覚 障害者や高齢者を対象に開発されたもので、音声以外にも、点字プリンタに接続すれば点字に、 パソコンに接続すればテキストとして出力することも可能である。

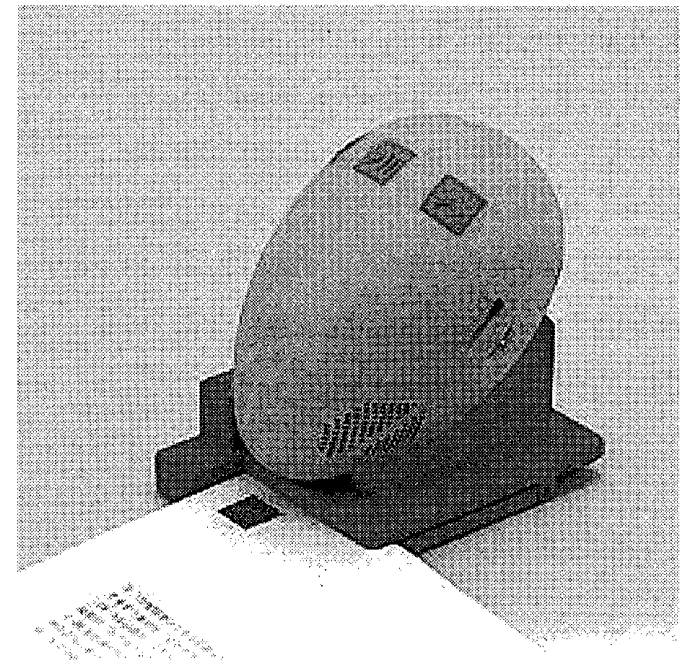

写真 1 スピーチオ

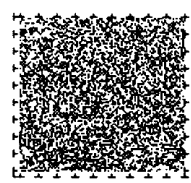

( $\mathrm{M}$ サイズ原寸)

第 1 図 SP コード

第 1 表 SP コードの仕様一覧

\begin{tabular}{|c|c|c|}
\hline サイズ & 大きさ $(\mathrm{mm})$ & $\begin{array}{c}\text { エンコード可能な } \\
\text { 日本語の文字数(字) } \\
\text { (圧縮率が異なるため、 } \\
\text { 下記文字数は一定ではありません) }\end{array}$ \\
\hline $\mathrm{XS}$ & $6.8 \times 6.8$ & 77 \\
\hline $\mathrm{S}$ & $12.4 \times 12.4$ & 343 \\
\hline $\mathrm{M}$ (標準) & $18.0 \times 18.0$ & 800 \\
\hline $\mathrm{L}$ & $19.9 \times 19.9$ & 984 \\
\hline
\end{tabular}

最小をXS サイズとして、S、M、Lまでデータ容量に合わせてサイズを可変できる。また英語 版の「SP コード」作成ツールも追加し、英語圈市場への展開も視野に入れている。

「スピーチオ」の仕組みは印字または印刷解像度 $600 \mathrm{dpi}$ 以上の「SP コード」を 131 万画素の CMOS イメージセンサで読み取り、格納されているテキストデータの音声出力をおこない、一時 


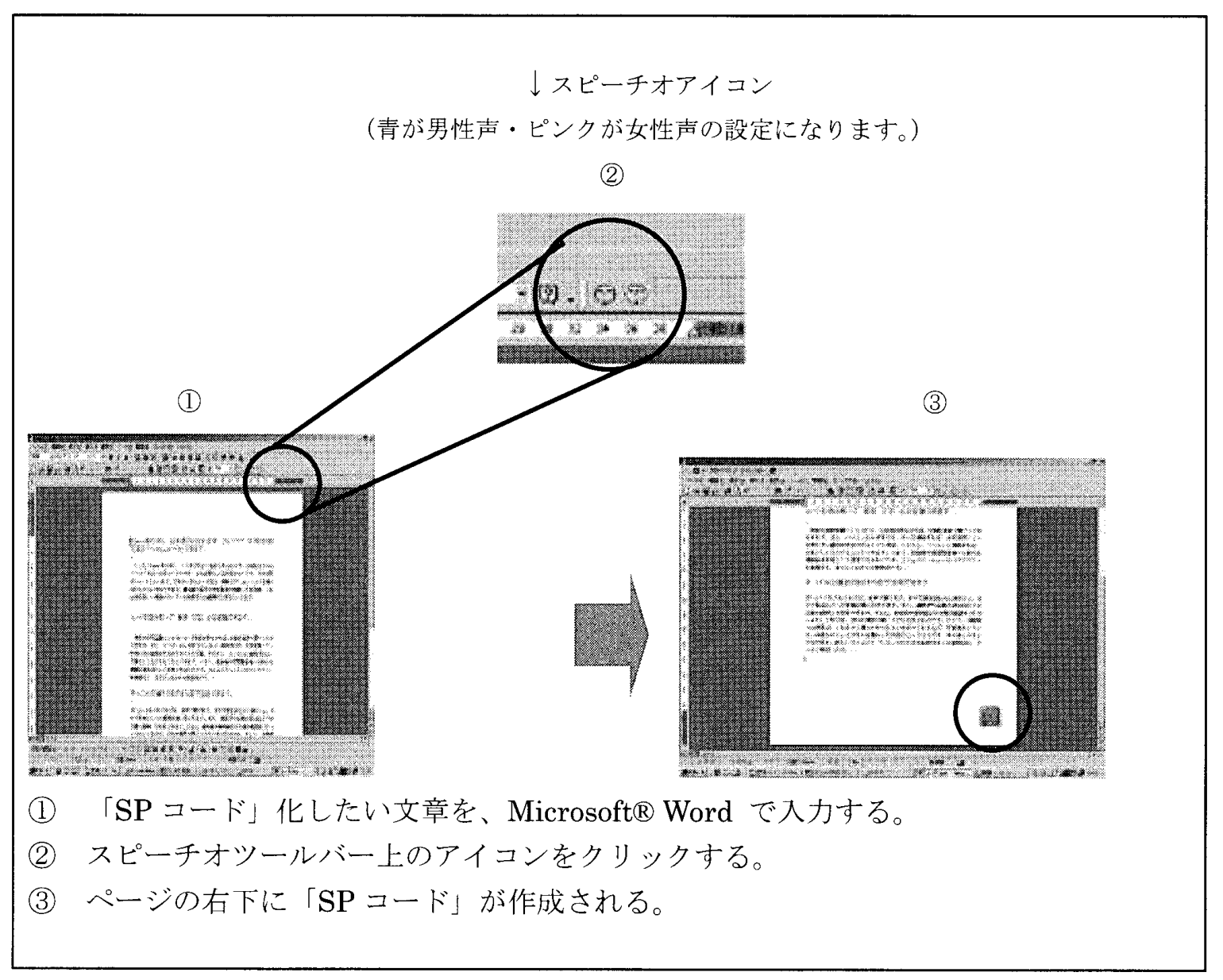

第2図「SPコード」作成フロー

\section{3. 活用例}

現在ユニバーサルデザインやバリアフリーを推進する企業、自治体は増加し、障害者や高齢者 に対する配慮が社会的に注目されている。視覚障害者数は約 40 万人（4） ロービジョン（弱 視）人口は約 100 万人（5）といわれている。従来、こうした方々への情報伝達手段としては、 拡大文字印刷物や、ボランティア団体などが朗読したカセットテープや CD、点字本であったが、 これらを作成するには非常に多くの手間やコストがかかるという問題があった。しかも点字が読 める人達の割合もせいぜい $10 \%$ 程度といわれている。印刷物作成時にあらかじめ情報を「SP ード」化することで、音声や点字で得ることができ、視覚障害者や高齢者の方々に対する情報格 差の軽減に寄与するため、自治体や福祉施設、図書館、教育機関等その他公共機関での利用が期 待されている。

官公庁、地方自治体では「広報誌」、通知文」、「お知らせ」などの印刷物への利用を考えてい ます。例えば、滋賀県八日市市では、視覚障害者の方々に各種「お知らせ」を「SP コード」付文書 にする動きが始まりました。「納税通知書」、「国民健康保険料決定通知書」、「福祉医療費受給券の 更新について」、「口座振替通知書」などに「SPコード」が付くようになりました。（6） また、 東京都練馬区においては平成 16 年 4 月 1 日発行の「障害者福祉のしおり」(全 112 ページ)に「S $\mathrm{P}$ コード」を印刷し、区の福祉施策の概要とサービス空口を紹介している。このことは新聞でも、 
報道され大きな反響を呼んでいる。（7）（8）

選挙公報、薬の効能や処方箋、一般書籍・雑誌、電話・電気・ガス・水道などの公共料金の請 求書、また、そば・うどん・寿司・ピザなどの出前・ケータリングサービスのチラシや料理のレ シピ、宅配便の不在通知、などに「SP コード」が付けば、日常生活の利便性を向上させるのに 役立つものと期待されている。具体例としては、福井県「みちしる心゙推進委員会」は JR 福井駅 時刻表の音声案内デー夕を入力した「音の出る時刻表」を完成させている。（9）（１０）

\section{活動状況}

この「SPコード」と「スピーチオ」は、開発メンバーとして視覚障害の方にも参加してもらい、 製品開発に努めてきた。また試作機ができ上がった段階で実際に各地のリハビリテーション施設 や都道府県の視覚障害者団体等でこの仕組みを体験してもらい、好評であった。また 2002 年 2 月に全米盲人会連合、開発委員会でスピーチオの英語版デモを行い、大変よい評価をいただいた。

「SP コード」は、まだ市場に流通していない 2 次元シンボルである。このシンボルを普及させ ていくためには、「スピーチオ」の普及とともにシンボルが入ったコンテンツを市場に流通させる 仕組みが必要である。私達晴眼者にとって一番身近な情報収集手段としての印刷物は視覚障害者 の方々にとっては最も遠い情報媒体でもある。私達が日常手にする、あらゆる印刷物に「SP コ一 ド」が添付されれば、視覚障害者の方々に積極的な情報提供と、仕事・学習・趣味など潤いのあ る生活環境を提供できると確信している。

\section{4. 今後の展開}

「スピーチオ」は、すでに価格 115,000 円で販売開始しているが、平成 15 年度、厚生労働省の 日常生活用具に指定されことで、1 級、2 級の視覚障害者の方々は、福祉予算で、国が $50 \%$ 、都 道府県が $25 \%$ 、区市町村が $25 \%$ を負担し、無償もしくは数千円で入手できることになった。また 印刷物作成のためのプロフェッショナル用の「SP コード」作成ツール「SP コードメーカプロ」も 価格 7600 円で利用できる状況となっている。新たなバリアフリー・コミュニケーション・システ ムのビジネスモデルを創出していきたい。

\section{参考文献}

（1）平成 15 年 4 月 1 日付け官報告示（号外第 71 号）厚生労働省告示第 158 号、159 号

(2)「SP コード」公式サイト http://www. sp-code.com

(3) 特許第 3499220 号 「二次元コード、二次元コードの読取方法、プログラムおよびコンピ ユータ読み取り可能な記録媒体」

（4）厚生労働省統計表データベースシステム http://wwwdbtk. mhlw. go. jp/toukei/kihon/data12/3-25. htm

（5）国立身体障害者リハビリテーションセンター http://www.rehab.go.jp/RehaNews/No217/2_story. htm1

（6）三菱総合研究所発行「自治体チャネル」2004 年 1 月号

（7）毎日新聞東京本社 平成 16 年 4 月 2 日 身近な話題、地域のニュース 一練馬区、聞く「障害者福祉のしおり」読上げ装置で再生可「区政情報を手軽に得て」一

(8) 朝日新聞東京本社 平成 16 年 4 月 6 日 音声で聞く福祉冊子

（9）日本経済新聞 平成 15 年 12 月 16 日 視覚障害者向けメニューを配布一ピザーラー （1０）福井新聞 平成 16 年 4 月 2 日 “音の出る時刻表”完成 